\title{
THE ROLE OF TOURISM INFORMATION CENTRES AND NATURE BASED PRODUCTS AND ITS IMPACT ON DARJEELING TOURISM AND SOCIO- ECONOMIC DEVELOPMENT, WEST BENGAL, INDIA
}

\author{
SK ABDUL GAFFAR ${ }^{1} \&$ DR. S. KISHORE KUMAR ${ }^{2}$ \\ ${ }^{1}$ Research Scholar, Department of Library and Information Science, Alagappa University, Tamil Nadu, \\ ${ }^{2}$ Deputy Librarian, Department of Library and Information Science, Alagappa University, Tamil Nadu
} \begin{abstract}
The role of tourist information centres and information systems and services both are playing a vital role in world tourism to attract the heterogeneous tourists in Darjeeling tourism. There are several Govt. tourists information centres and private information system and services like as Gorkhaland Territorial Administration (GTA) and West Bengal tourist development corporation (WBTDC) Government of West Bengal19 and 'Make my trip','Trivago', several hotel companies, Airlines travel agencies and guides books and e-books are available to guide the updated information on Darjeeling tourism. Tourism products which would provide the satisfaction of tourists regarding physical and psychological aspects during their traveling. Tourism products can access the tourists by well-designed services from every aspect like as available information in particular tourism location, accommodation, transport and entertainment which meet the user's required satisfaction. On the other hand, in Darjeeling, nature-based tourism products such as areas, climate, landscape, wildlife and natural environment like tea guarding, water rafting, bird watching tour, butterflies tours, and forest safaris are famous in the queen of the hills; geographical location and climate of Darjeeling also tourists-friendly. These are also one of the major reasons why tourists are coming here from across the world. Darjeeling(Queen of the Hills) is one of the most wonderful hill resorts throughout the globe. Its snow peaks, peaceful and lively green hills steeped in luxury. Natural tourism products are the most attraction of tourists in Darjeeling and at the same time, it is also playing an important role in its socio-economic development.
\end{abstract}

KEYWORDS: Tourism information Centre, tourists, 'Queen of the Hills', Darjeeling Natural Tourism, Nature-based Products.

Received: Dec 11, 2020; Accepted: Jan 01, 2021; Published: May 03, 2021; Paper Id.: IJLSRJUN20211

\section{INTRODUCTION}

Tourist inflows into this peaceful and lively green hill because, many reasons are there, among them nature-based tourism is the main attraction of the tourists. The nature-based tourism products in Darjeeling are like areas, climate, landscape, wildlife, snow peaks, tea tourism, water rafting, bird watching tour, butterflies tours, and forest safaris are famous in the queen of the hills. Each year more than one lakh (100000) domestic as well as foreign tourists have visited this green land. (India Today Survey, $23^{\text {rd }}$ December 2015). For promoting and providing better services of Darjeeling tourism, Tourism information Centres like Gorkhaland Territorial Administration (GTA) and other is run by West Bengal tourist development corporation (WBTDC)and some areby the government of India (https://en.wikipedia.org/wiki/Darjeeling). The geographic allocation and climate of Darjeeling also tourists-friendly. It is also one of the major reasons why tourists are coming here from across the world. 


\section{1: Geography and Climate of Darjeeling}

Geographical location and climate of Darjeeling are helpful for nature-based products, and it becomes a tourist-friendly, which is the main attraction of tourism. Details of the climate throughout the year and tourism map of Darjeeling are given below.

\subsection{1: Tourism Map of Darjeeling}

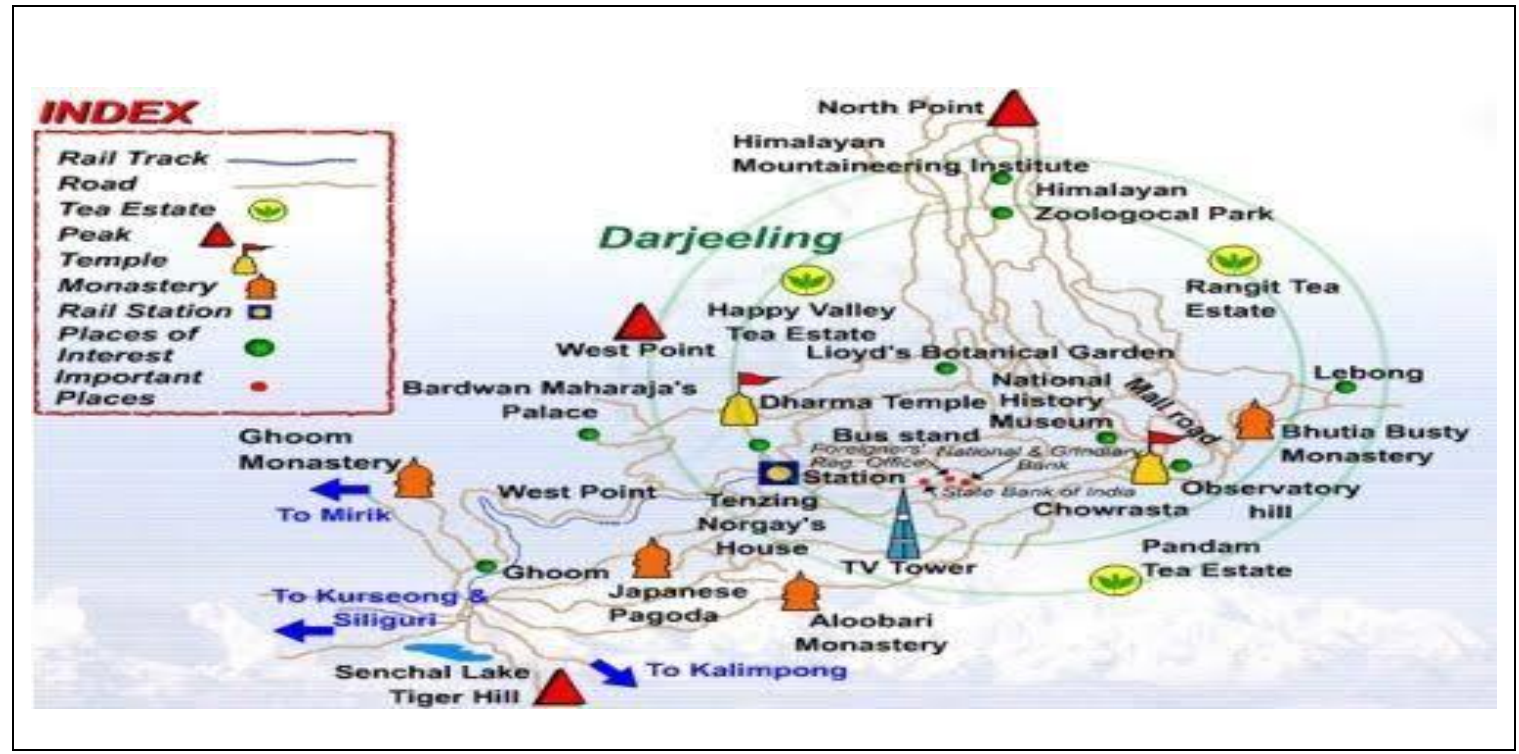

Figure 1: Source: https://www.google.com/search

Darjeeling is the headquarter and the main town of the Sadar subdivision. It is located at an elevation of 6,700ft (2000m) in the main Darjeeling hill region.

Table: 1.1.2: Darjeeling Weather by Month/Weather Averages

\begin{tabular}{|l|c|c|c|c|c|c|c|c|c|c|c|c|}
\hline & January & February & March & April & May & June & July & August & September & October & November & December \\
\hline $\begin{array}{l}\text { Avg. } \\
\text { Temperature ("C) }\end{array}$ & 6.6 & 8.1 & 11.7 & 14.7 & 16.1 & 17.3 & 17.8 & 17.8 & 17.5 & 15.3 & 11.5 & 8.4 \\
\hline $\begin{array}{l}\text { Min. } \\
\text { Temperature ("C) }\end{array}$ & 3.3 & 4.6 & 7.9 & 10.9 & 13 & 14.9 & 15.5 & 15.5 & 14.8 & 11.6 & 7.5 & 4.6 \\
\hline $\begin{array}{l}\text { Max. } \\
\text { Temperature ("C) }\end{array}$ & 9.9 & 11.6 & 15.5 & 18.6 & 19.2 & 19.7 & 20.2 & 20.2 & 20.2 & 19 & 15.6 & 12.3 \\
\hline $\begin{array}{l}\text { Avg. } \\
\text { Temperature ("F) }\end{array}$ & 43.9 & 46.6 & 53.1 & 58.5 & 61.0 & 63.1 & 64.0 & 64.0 & 63.5 & 59.5 & 52.7 & 47.1 \\
\hline $\begin{array}{l}\text { Min. } \\
\text { Temperature ("F) }\end{array}$ & 37.9 & 40.3 & 46.2 & 51.6 & 55.4 & 58.8 & 59.9 & 59.9 & 58.6 & 52.9 & 45.5 & 40.3 \\
\hline $\begin{array}{l}\text { Max. } \\
\text { Temperature ("F) }\end{array}$ & 49.8 & 52.9 & 59.9 & 65.5 & 66.6 & 67.5 & 68.4 & 68.4 & 68.4 & 66.2 & 60.1 & 54.1 \\
\hline $\begin{array}{l}\text { Precipitation/ } \\
\text { Rainfall (mm) }\end{array}$ & 17 & 15 & 41 & 86 & 166 & 468 & 710 & 529 & 375 & 121 & 15 & 4 \\
\hline
\end{tabular}

Source: Climate-Data.org (mean temperatures) between the driest and wettest months, the difference in precipitation is $706 \mathrm{~mm}$. The variation in annual temperature is around $11.2{ }^{\circ} \mathrm{C}$.

\section{NATURE BASED PRODUCTS OF DARJEELING: An Overview}

The study covers the main natural tourist spots like as Tea-garden, Hills, waterfall, RiverBird watching and their contribution to Darjeeling tourism for its socio-economic development and the same time the tourism information centre also playing an important role for promoting and development of Darjeeling tourism. 


\section{REVIEW OF THE LITERATURE}

Some of the closely related studies are included herewith.

Cox (2009) in his study revealed that most of the tourists have not followed the most trustworthy source of travel information. They never followed non-UGC (user-generated content) websites. They consider tourism websites or airline websites more than UGC. It is not trusted worthy. This has been mentioned by the participant that they are more like the information provided by state tourism websites. Respondents also remarked that when traveling operators' responses with UGC online post. In the same way, the user felt that available websites of tourism and hospitality can enhance by support to UGC. Through this, tourism providers can reach their e-commerce business to the consumer by integrating UGC activities into their websites. Hospitality and tourism organization cannot avoid UGC provided information. It is also helpful to make trips comfortable.

Lone (2017) in his study shows that $88 \%$ of the respondents used the internet for their information search. While more than $47 \%$ of the respondents use audio/video/DVD/cd-room as an information source. The majority of the respondents mentioned that the problem is information scatters in many sources and $34 \%$ of the user revealed that important information is not available and few others opined lack of technical support and expansive.

Rufaro et al. (2008)expressed their views that information is a priceless asset of the business, demand by SMME for information services are not sufficient. It can be expanded through an awareness program, direct contract with SMME, etc. It is a very rare chance to establish a parting stand-alone information service for SMME's on commercial business. But there is room for services providers of Namibia to work jointly for better information for the SMME sector. This sector contributes to national GDP.

\subsection{Objectives of the Study}

The following objective has framed in the study.

- To find out the tourism information Centres available in Darjeeling

- To find out the role of the tourism information Centres for promoting tourism in Darjeeling.

- To find out the nature-based tourism products.

- To find out the contribution of the nature-based products in Darjeeling socio-economic development.

\section{METHODOLOGY}

The study has conducted based on empirical observation and data has been taken from different journals, e-journals, e-books, reports on several websites and blogs. Collection data through some related literature review and also data collected through telephonic conversations in tourism information centers and travel agencies who are actively engaged with tourist information centers and information systems and services. Based on the secondary data study has frame out.

\section{SIGNIFICATION OF THE STUDY}

The study also critically evaluates information services provided by Darjeeling and West Bengal Tourism Sectors. On the other hand, it is evaluating the services provided by other sectors like 'Make my trip', 'Trivago', several Hotel Company, Airlines Travel Agency and guides books and e-books are available to provide the right information about the Darjeeling 
tourism.

\section{SCOPE OF THE STUDY}

The study intends to cover important tourist information centers, information system and services (Govt. and Private) and nature-based tourism products in Darjeeling tourism.

\section{LIMITATION OF THE STUDY}

The Study is limited with covered the main tourist information centers, information system and services (Govt. and Private)and nature-based tourism products in Darjeeling.

\section{ROLE OF TOURISM INFORMATION CENTRES AND OTHER PRIVATE ORGANISATION IN DARJEELING}



Figure 2: Tourism information Centres in Darjeeling

There are several tourist information Centre that exists in Darjeeling and other places in India to provide information about Darjeeling tourism as well as to lodge booking for the right price. For example, GTA is run by an administrative body of Darjeeling hills and others run by west Bengal Tourist Corporation (WBTDC), West Bengal Tourism Centres at Siliguri, NJP, Bagdogra, and some others run by Govt. of India. We Bengal state tourism centers providing information not only Darjeeling provides throughout the state as well, from here, but you can also book the staterun tourist lodges in Darjeeling hills.

In Darjeeling, Govt. Tourism Department, as well as private agencies, likes "Make my trip", "Trivago", many Hotel Company, Airlines travel agency, and many guide books and e-books are available to provide the accurate information about Darjeeling Tourism. 


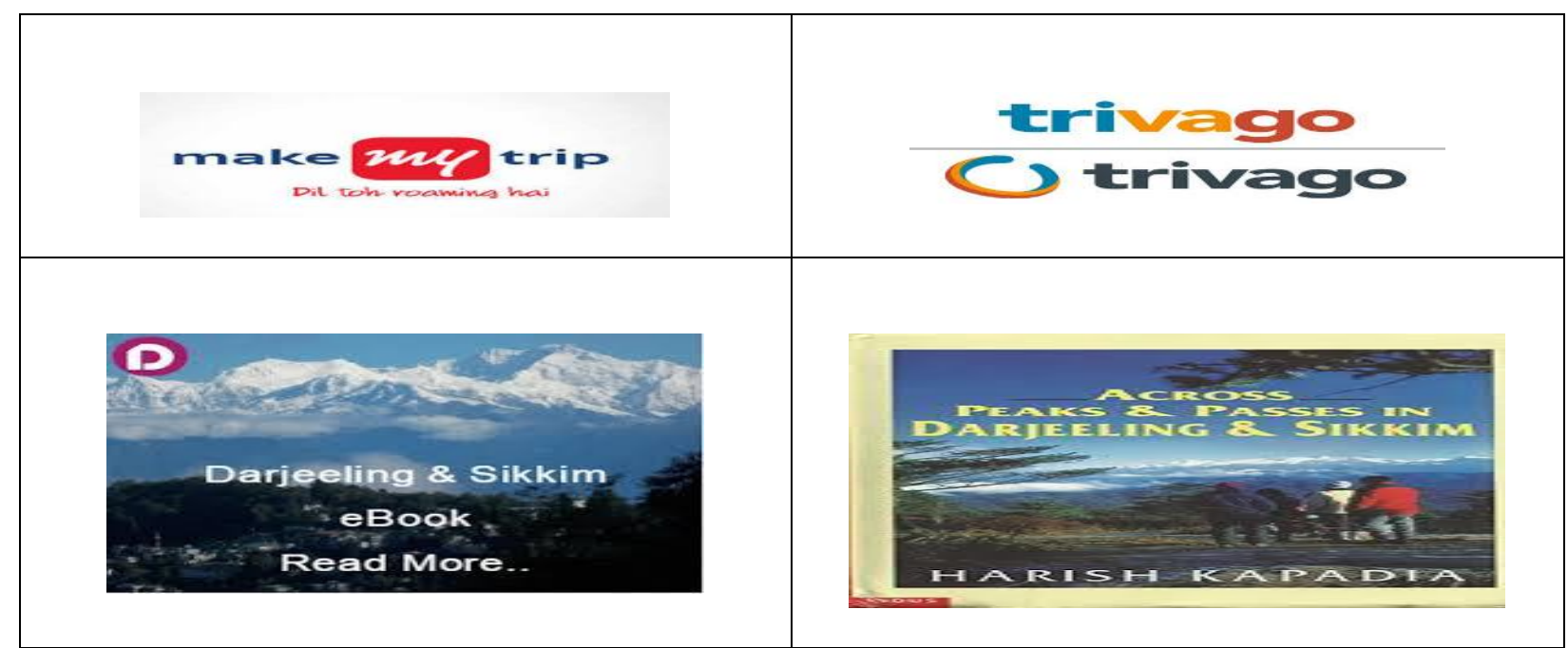

Figure 3: Private Agencies Like "Make my Trip", "Trivago", Guides Books and e-Books Provide, Sources, (makemytrip.com, trivago.com)

\section{SOME OF THE NATURE BASED TOURISM PRODUCTS IN DARJEELING}
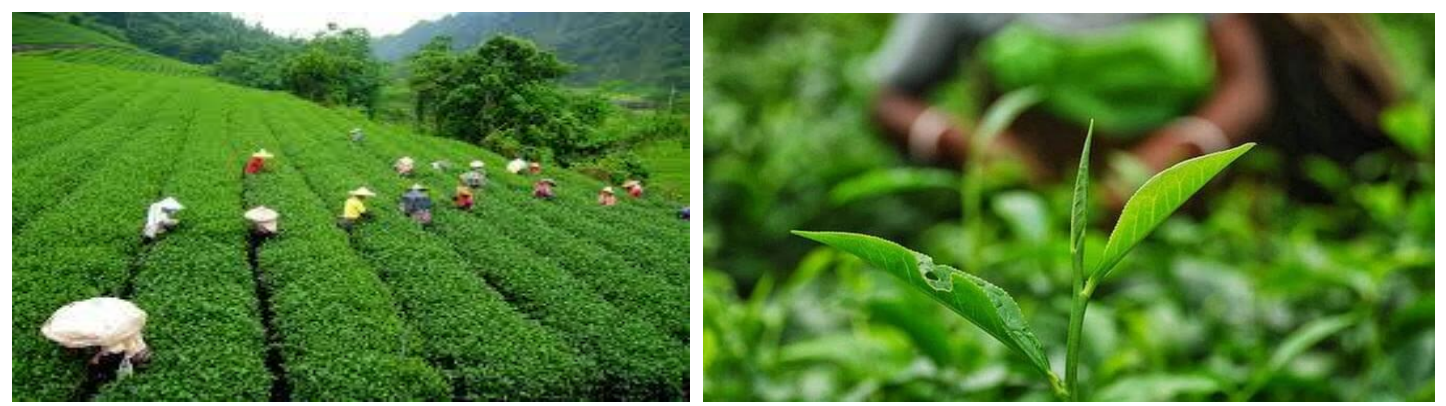

Figure 4: Doors Tea-Garden in Darjeeling (Source, https://traveltriangle.com)

Tea-gardening is one of the greatest nature-based products in Darjeeling. And it is world-famous for its test and flavor for the reason peoples are coming from across the world to traveling here. This product contributes $7 \%$ of the total tea of India. It brings the most effectiveness in Darjeeling's socio-economic development. The beautiful tea gardens on the slopes of rolling hills are continuous attracting the tourist here so far.

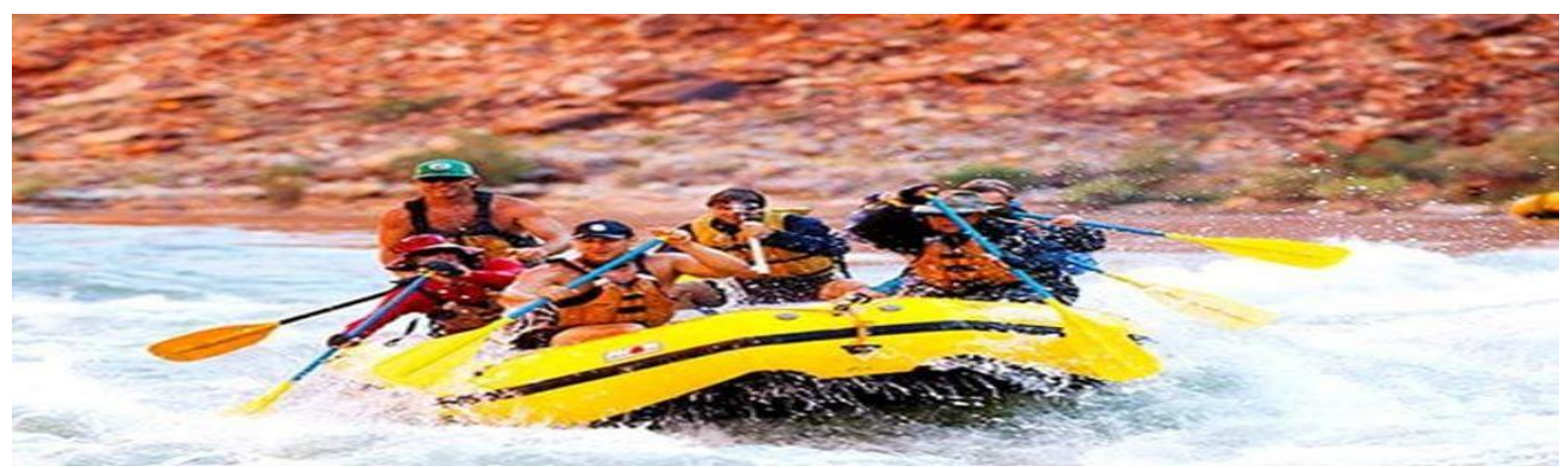

Figure 5: Teesta, Source, (https://traveltriangle.com)

Teestariver is one of the best river rafting in India. This is also attracting the tourist in the summertime in Darjeeling. This is given only the trained peoples because there is a high level of danger. 


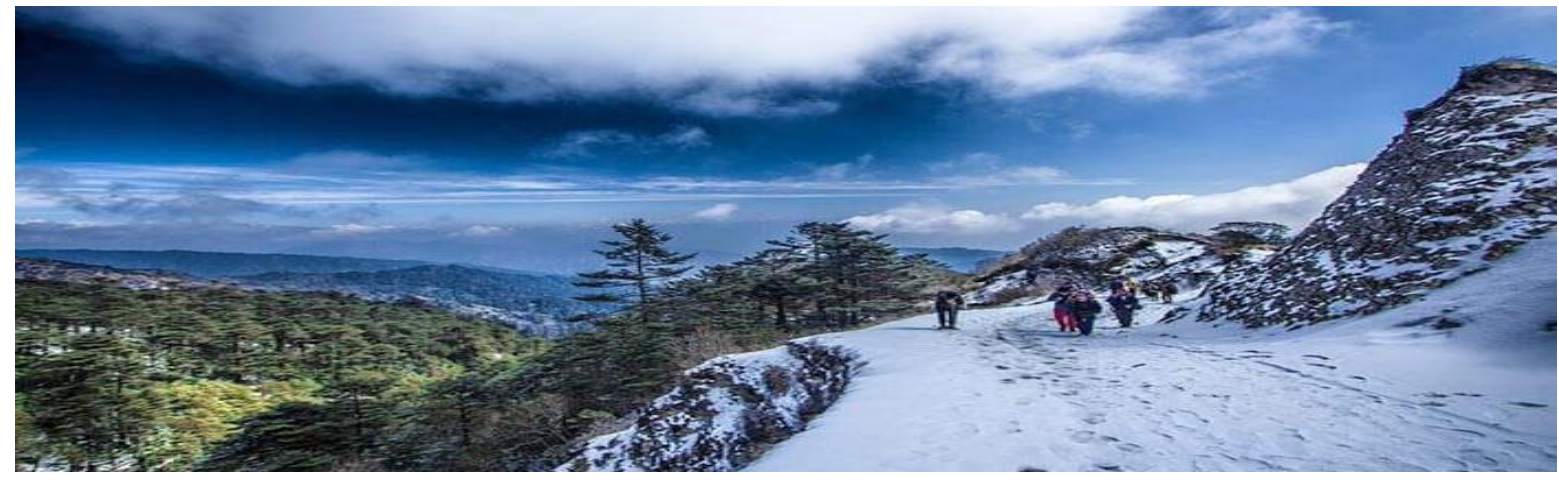

Figure 6: Sandakphu, Source, (https://traveltriangle.com)

Sandakphu is essential for adventure curiosities, it is the highest point in the West Bengal and it is an ideal destination for flying devotees. Located astounding height of $3636 \mathrm{~m}$.

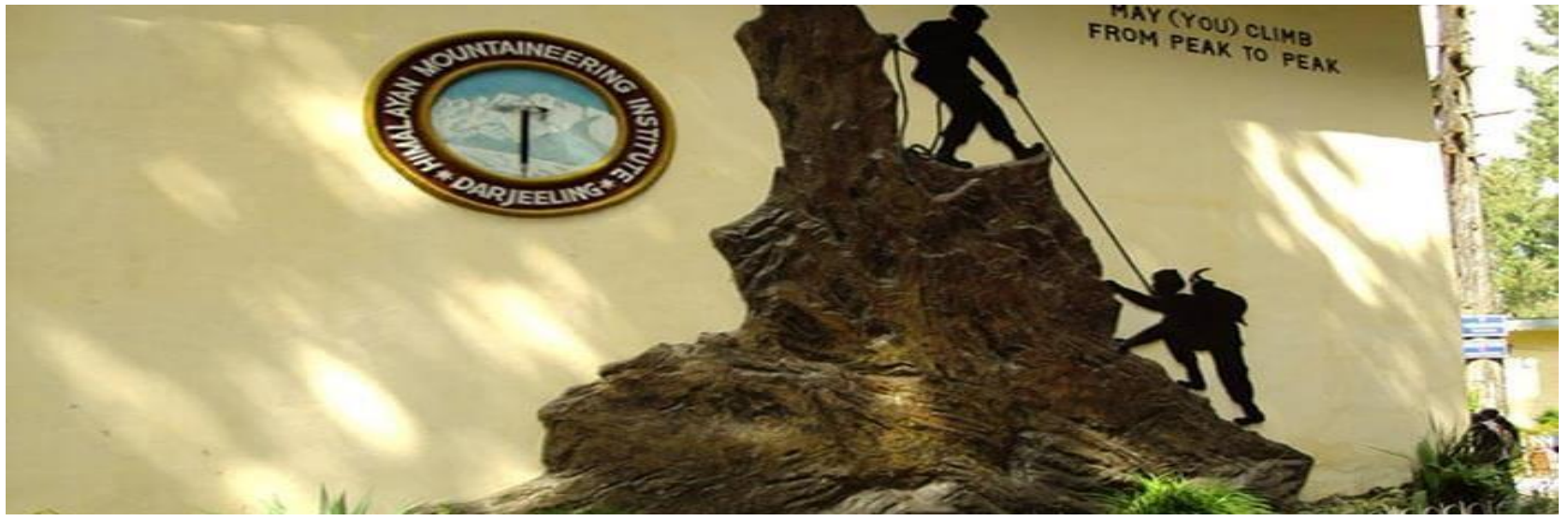

Figure 7: Himalayan Mountaineering Institute, Source, (https://traveltriangle.com)

The Himalayan Mountaineering Institute located at JawaharParvat" in Darjeeling, conducts the mountaineering and other several courses at various levels of ranging from beginning to expert, sometimes tourist also takes part in this course. Because sometimes it is offered for a few days. It is taking fess very less INR 4000/ candidate.

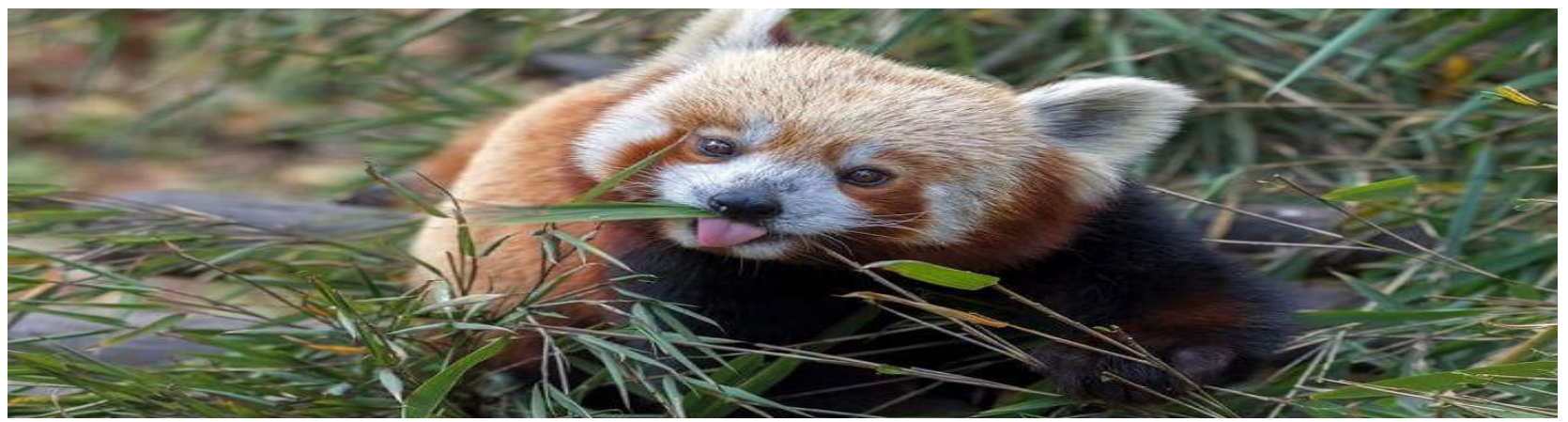

Figure 8: Padmaja Naidu Himalayan Zoological Park, Source, (https://traveltriangle.com)

The Padmaja Naidu Himalaya Zoological Park is located in the famous town in Darjeeling. The tourists are getting ready to meet the endangered Himalayan wolf, the red panda, snow leopards, and several others. It is located at "Jorethang Road, Near Birch Hill Resort, Jawahar Parbat, and Darjeeling". 


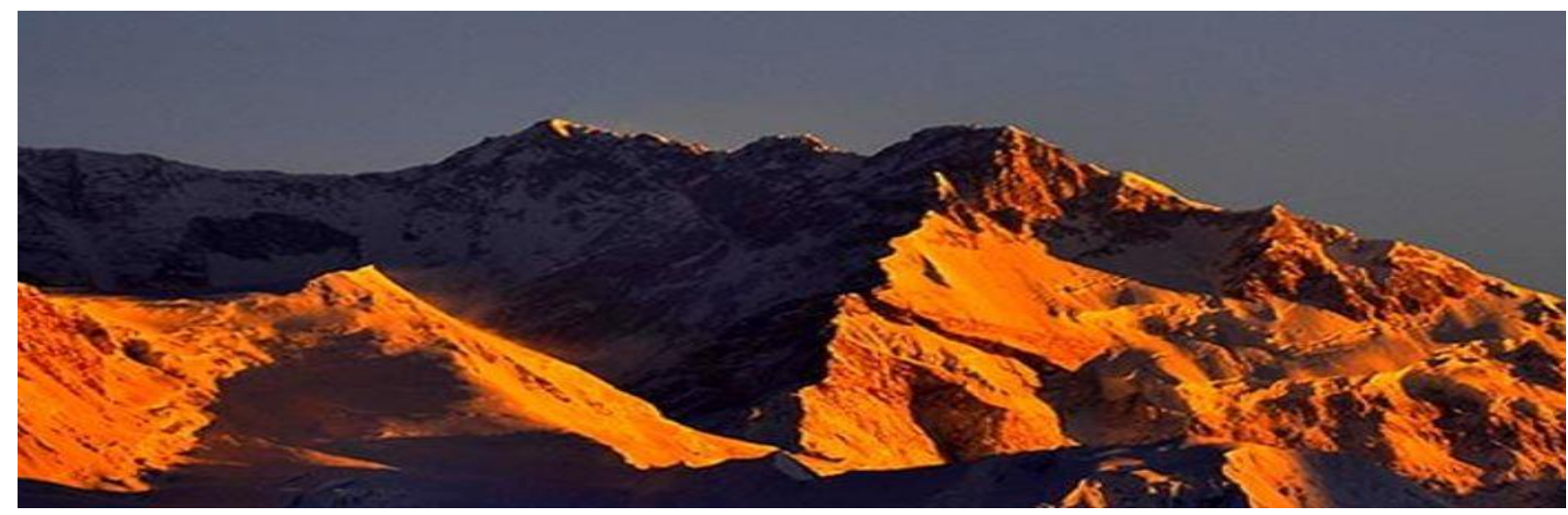

Figure 9: Tiger Hill, Source, (https://traveltriangle.com)

It is saying that your trip is unsuccessful until you have to witness the sunrise at Tiger Hill. This is one of the best attractions for tourists in Darjeeling.

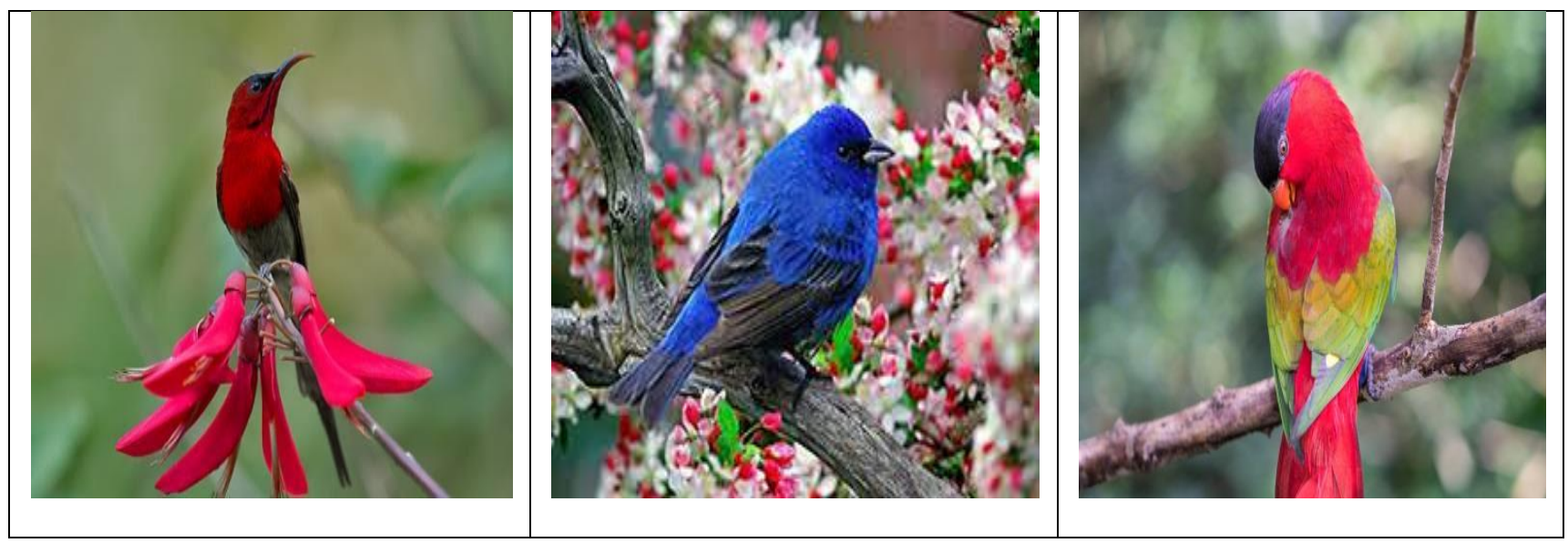

Figure 10: Bird watching in Darjeeling Hill Source, (https://traveltriangle.com)

Bird watching in Darjeeling is one famous spot in green hills. Different colored birds are available there in hills. In the evening you must enjoy the twists of thousands of birds. This also not less important in Darjeeling tourism and tourist.

\section{CONTRIBUTION OF THE NATURE-BASED PRODUCTS IN DARJEELING SOCIO- ECONOMIC DEVELOPMENT}

Major contributions of Darjeeling's economy are nature-based tourism products and services. Here, the Tea industry and other natural products are like waterfalls, hills, beautiful rivers, lakes and bird watching are famous. Every year 50000.00 foreign and 50000.00 domestics tourists traveled here in Darjeeling district (India Today Survey, $23^{\text {rd }}$ December 2015). it is unique agro-climate condition has an exceptional natural flavor and famous for the tea industry. It is also got a Geographical Indicator (GI). According to Darjeeling Indian Tea Association (DITA) is located at Darjeeling declared that each year Darjeeling produced $9000000.00 \mathrm{~kg}$ (7\% total of India) tea from India. Several Bollywood, Tollywood, and other movies have been shouted here, which are directly related to increasing its economic growth and socio-economic development. 


\section{RECOMMENDATION AND CONCLUSION}

In future endeavours Darjeeling nature-based tourist products would catch more tourists; if it is properly taking care of by tourist information centres and information systems and services as well as Govt. of Darjeeling and West Bengal so far. It's world-famous "Queen of the Hills" and unique flavour of the Tea is needed more care from Govt. side. Each year more than one lakh (100000) domestic as well as foreign tourists have visited this green land. (India Today Survey, $23^{\text {rd }}$ December 2015). For promoting and providing better services of Darjeeling tourism, Tourism information Centres like Gorkhaland Territorial Administration(GTA)and other is run by West Bengal tourist development corporation (WBTDC) are playing a very important role to reach its awareness at world doors. On the other hand, the location and climate of Darjeeling also tourists-friendly. It is also one of the major reasons why tourists are coming here from across the world. The study found that, natured based tourism products and its value for economic development in Darjeeling. For its geographical location and climate more attract with its green hills, snow peaks, tea-gardening gave it a unique flavour to the tourists in Darjeeling.

\section{REFERENCES}

1. Cox, C.( 2009). The Role of User-Generated Content in Tourists' Travel Planning Behavior. Journal of Hospitality Marketing \& Management,18(8): 743-764.

2. Krause, J.(2017)Semantic heterogeneity: comparing new semantic web approaches with those of digital libraries. Library Review, 57(3): 235 - 248 .

3. Lone, S. A. et. Al. (2017). Information Seeking Behavior of Research Scholars of Faculty of Social. International Journal of Library and Information Studies, 7(1): 62-77.

4. Mchombu, K. J.(2016). Information needs and seeking habits for rural development in southern Africa, 32p.

5. Rufaro, E, et.al (2016). Information Needs and Information Seeking. SAGE Publications, 24(1).

6. https://www.google.com/search?q=tourism+in+west+bengal \&oq=Tourism+in+West+Bengal\&aqs=chrome.0.35i39j0l4j69i6 $0.1163 j 0 j 7$ \&sourceid $=$ chrome \&ie $=U T F-8($ Accessedon, 2019, August Friday).

7. Majid, S. \& Kassim, M. G.(2016). Malaysian Journal of Library \& Information Science,5(2)

8. Banerjee, Aliv.(2011). ISSUES AND CHALLENGES OF TOURISM DEVELOPMENT IN WEST BENGAL.INTERNATIONAL CONFERENCE ON MANAGEMENT (ICM 2011) PROCEEDING,1-20p.

9. Banerjee, D.(2018). IMPACT OF EMPLOYEE INVOLVEMENT ON PROVIDING QUALITY SERVICES IN TOURISM SECTOR FOR DEVELOPING NATION'S ECONOMIC POTENTIAL-A study on West Bengal. International Journal of Business and Applied Social Science, 4(7): 1-11.

10. https://www.google.com/search? $q=$ Tourist + Information + Center,+ Bhanu + Sarani,+ Darjeeling + image $\& t b m=i s c h \& s o u r c e=i u$ \&ictx=1 \& fir=LIRrPMEtSP7MuM\%253A\%252CaAgnf3aT-NvAPM\%252C_\&vet=1\&usg=AI4_-kTYojHoquVDVxO5r9q-6G (Accessed on November 2019)

11. Bhattacharya, S.(2013) A STUDY ON ADVENTURE TOURISM AS AN EMERGENT SECTOR IN WEST BENGAL, 1-384p.

12. Bhutia, D. S.(2015) Sustainable Tourism Development in Darjeeling Hills of West Bengal, India: Issues \& Challenges. Global Journal of HUMAN-SOCIAL SCIENCE: B Geography, Geo-Sciences, Environmental Science \& Disaster Management,15(3): 3-11p.

13. Global Journal of HUMAN-SOCIAL SCIENCE, (n.d.).

14. GOVERNMENT OF WEST BENGAL(2016). West Bengal Tourism Policy, 1-12p. 
15. Karim, R., \& Ahamed, D. M. MARKETING OF RUR(2019). AL DESTINATIONS AS A TOURISM PRODUCT: A CASE STUDY OF SELECTED AREAS IN WEST BENGAL, INDIA. Journal of Emerging Technologies and Innovative Research (JETIR, 6(3): 1-7p.

16. Malaysia, U. S. The State of the Art and its Sustainability. Proceedings of Regional Conference on Tourism Research,1-381p.

17. Mondal, S.(2016). West Bengal -A Tourist Destination Comparative Analysis of Bengal. Arabian Journal of Business and Management Review, 1-4p.

18. https://en.wikipedia.org/wiki/Darjeeling (accessed on 15 th November 2019) 
